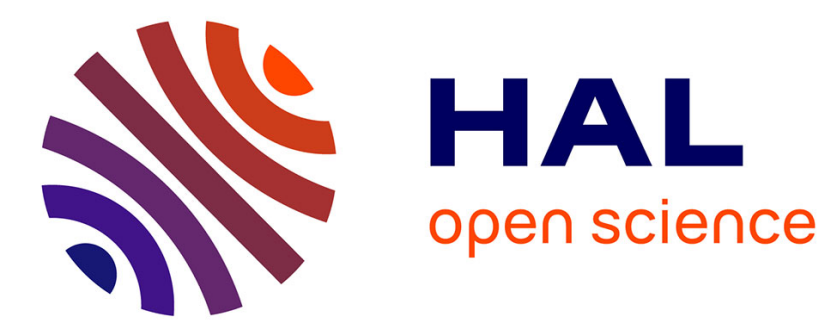

\title{
Red blood cell exchange in children and adolescents with sickle cell disease
}

\author{
E. Merlin, O. Hequet, J. Kanold
}

\section{To cite this version:}

E. Merlin, O. Hequet, J. Kanold. Red blood cell exchange in children and adolescents with sickle cell disease. Transfusion and Apheresis Science, 2019, 58, pp.136 - 141. 10.1016/j.transci.2019.03.006 . hal-03485096

\section{HAL Id: hal-03485096 https://hal.science/hal-03485096}

Submitted on 20 Dec 2021

HAL is a multi-disciplinary open access archive for the deposit and dissemination of scientific research documents, whether they are published or not. The documents may come from teaching and research institutions in France or abroad, or from public or private research centers.
L'archive ouverte pluridisciplinaire HAL, est destinée au dépôt et à la diffusion de documents scientifiques de niveau recherche, publiés ou non, émanant des établissements d'enseignement et de recherche français ou étrangers, des laboratoires publics ou privés.

\section{다)(1) $(5$}

Distributed under a Creative Commons Attribution - NonCommerciall 4.0 International 


\section{Red blood cell exchange in children and adolescents with}

\section{sickle cell disease}

\section{Merlin $\mathbf{E}^{1}$, Hequet $\mathbf{O}^{2}$, Kanold $\mathbf{J}^{1}$}

${ }^{1}$ Apheresis unit, Service d'Hémato-Oncologie et Thérapie Cellulaire

Pédiatrique, Centre Hospitalier Universitaire, Clermont-Ferrand, France

${ }^{2}$ Apheresis unit, Etablissement Français du Sang Rhône Alpes, Centre

Hospitalier Lyon Sud Pierre Bénite, France.

\section{Corresponding author}

Etienne Merlin

Apheresis unit, Service d'Hémato-Oncologie et Thérapie Cellulaire Pédiatrique,

Centre Hospitalier Universitaire, Clermont-Ferrand, France.

Phone : +33473750015

Email : e_merlin@chu-clermontferrand.fr

Number of pages: 20

Number of tables: 2

Number of figures: 0

Number of references: 39 


\begin{abstract}
Automatic red blood cell exchange i.e. using devices (RBCX) has become a standard therapy to remove abnormal red blood cells (RBC) in adults and children affected by sickle cell disease ( $\mathrm{SCD})$. This treatment is performed both in emergency to treat acute complications and through a regular program of $\mathrm{RBCX}$ to prevent the recurrence of complications. However, small children, i.e. those with a low body weight, height and total blood volume, are at risk of relative hypovolemia and metabolic complications during the procedure. Moreover, the peripheral venous access is limited among young children, which requires alternative short- or long-term venous access. These two main limiting factors necessitate adaptations of the procedures and subsequent monitoring during and after the sessions. However, performing RBCX in children requires other adaptations and cautions that must be considered. Our review summarizes the limits, safety precautions and the adaptations of the techniques to ensure RBCX in children.
\end{abstract}

\title{
1. Overview of red blood cell exchange in children
}

\subsection{Introduction}

Sickle cell disease (SCD) is caused by a point mutation in the sixth position of the $\beta$ globin gene leading to polymerization of hemoglobin $\mathrm{S}(\mathrm{HbS})$ at low oxygen tensions, this polymerization of deoxygenated HbS promoting red blood cell (RBC) sickling (1). Decreased deformability and increased fragility of sickled RBCs are at the origin of enhanced hemolysis in SCA patients and frequent painful vaso-occlusive events (1-2). Recurrent vaso-occlusion events cause further endothelial dysfunction and inflammation, resulting in progressive tissue and organ damages (3-4). These abnormalities generate severe complications very early in the childhood, such as stroke and cerebral macrovasculopathy as well as acute chest syndrome 
(ACS) or vaso-occlusive crisis (VOC) in the youngest children (5). Associated or not to the previous problems, other complications have been recently described in older children with SCD, such as hormonal insufficiency, growth delay, abnormal puberty, bone complications and recurrent VOC preventing a normal schooling and sport practices (6-7).

The replacement of abnormal hemoglobin and sickled RBCs improves the clinical status of the SCD-children. This replacement was originally achieved by prophylactic transfusions associated with manual blood-letting but this technics allowed a limited exchange of abnormal RBC and did not prevent iron overload (8). RBC exchange using an apheresis device can replace a bigger amount of RBCs without inducing iron overload (8-10). Several studies showed its safety and efficiency in preventing the occurrence of SCD complications when regularly performed in children (8-9,11-12). However, the several limitations such as extracorporeal volumes of the $\mathrm{RBC}$ exchange circuits and the venous access difficulties limit their use in low-weight children. Moreover, other factors must be taken into account to perform safe and appropriate RBC exchange and to optimize the medical care in children. Thus the aim of this review is to describe the particular issues when performing RBCX in children and adolescents. For this purpose, the main recent studies describing advances concerning the use of transfusions or RBC exchange in SCD are shown in Table 1, whereas the articles describing recent guidelines and recommendations are shown in Table 2.

\subsection{Red blood cell exchange: indications}

The American Society of Apheresis published its guidelines, with recommendations ranging from grade $1 \mathrm{~A}$ (strong recommendation, high-quality evidence) to $1 \mathrm{C}$ (strong recommendation, low-quality evidence) until $2 \mathrm{C}$ (weak recommendation, low-quality evidence) (13) (Table 2). Considering these guidelines in acute SCD-complications, acute stroke and ACS were considered as $1 \mathrm{C}$ whereas priapism, multiorgan failure, hepatic/splenic 
sequestration and intrahepatic cholestasis were considered as 2C. In non-acute indications, RBC exchanges are recommended in stroke prevention associated or not with iron overload (grade 1A), in recurrent vaso-occlusive pain crisis (2C) and in pre-operative management (2A). In children indications are nearly similar to adults and in practice, RBC exchanges are indicated and recommended when acute complications occur and during programs for primary or secondary recurrent stroke prevention or when hydroxyurea fails to prevent ACS or severe VOC (11-13). Initially, the target level of $30 \% \mathrm{HbS}$ or less was classically recognized as preventing stroke (14-15). However, the recent American guidelines and consensus conference have qualified this target to $30-50 \% \mathrm{HbS}$ when cerebral vasculopathy remains stable for 3 years after the initial event $(13,16)$ (Table 2). Consequently, maintenance of the $\mathrm{HbS}$ target at low levels to prevent stroke recurrence is an important issue in children that is still debated.

\subsection{Red blood cell exchange: manual or automatic? Advantages and drawbacks}

RBC exchange can be performed manually associating blood-letting and transfusion or automatically using appropriate instruments and disposables. Only a few studies compared automatic and manual RBC exchanges (8-11,17-18). These studies did not exchange the same amount of RBCs. As compared with manual RBC exchanges, automatic RBC exchanges (designated here as RBCX) displayed increased levels of catheter-related complications (17). However, RBCX have demonstrated several advantages: they allow for removal of larger amounts of SCD-RBCs i.e. decreasing $\mathrm{HbS}$ at low levels, and are more efficient at maintaining the target of $30 \% \mathrm{HbS}$ or $30-50 \% \mathrm{HbS}$; hematocrit (Hct) fluctuations are well controlled during the procedures which reduces the risk of transient hyperviscosity during or after the session and allow a rigorous control of RBC balance, decreasing iron overload (8$10)$. 


\section{RBCX in children: specificities and cautions. Aim of this review}

\subsection{General considerations about apheresis}

Performing apheresis in children requires taking into account many age-related specificities of children. Some of them are obvious, such as total blood volume (TBV) or venous access. However, the overall success of the process relies on comprehensive care including psychological, social and logistical concerns. The process of apheresis in children has been extensively described in several publications (19-21). In summary, a special consideration must be accorded to the preparation of the session: intake contact with the child and family, explain and re-explain the aim of the treatment by using appropriate speech, take time, prevent pain by applying lidocaine and/or using MEOPA inhalation, and warm up the patient before puncture.

\subsection{Does apheresis supplant transfusion or manual exchange at every age?}

The benefit of a process of care depends on a subtle balance between immediate and long term benefits, immediate approval, and immediate and delayed risks. In the smallest children, the TBV is approximated by the formula TBV $=70 \mathrm{~mL} / \mathrm{kg}$. Thus, the total $\mathrm{RBC}$ volume (TRBCV) is: TRBCV $=\mathrm{Ht} \times 70 \mathrm{x}$ body weight. As an example, for a $10 \mathrm{~kg}$ boy with SCD who has a Hct of $20 \%$, TRBCV is about $140 \mathrm{~mL}$, which equals the volume of RBCs contained in a $60 \%$ hematocrit $233 \mathrm{~mL}$ RBC unit (RBCU). Given that the priming volume of a cell separator exceeds $140 \mathrm{~mL}$, the interest in apheresis appears questionable. Moreover, between 1 year and 14 years, the need of iron is about $10 \mathrm{mg} / \mathrm{day}$. One RBCU of $233 \mathrm{~mL}$ contains about $200 \mathrm{mg}$ iron. Hence, unless there is a vital emergency, in children less than 20 
$\mathrm{kg}$, it appears more beneficial to perform transfusion rather than $\mathrm{RBC}$ exchange. One issue should be a rapid increase in Hct, leading to a hyperviscosity. To prevent such an adverse event, we believe that it is preferable to perform iterative small transfusions (from the same donor), with the inhibition of erythropoiesis resulting in progressive decrease of $\mathrm{HbS}$ without deleterious increase of Hct. However, some teams have performed RBCX in young children with a $20 \mathrm{~kg}$ body weight or less (22-23). If RBCX are decided for in young children, adaptations of the procedures are required.

\subsubsection{Small children}

In the smallest children, the timing of apheresis should be adapted to the patient's habits. We recommend adapting the apheresis schedule to start just after feeding and just before the child usually has a nap. Peripheral venous access should necessitate a dedicated device, such as a little tablet to immobilize the arm. If necessary, parents are welcome even in the child's bed to reassure them. However, sometimes despite all these proceedings a sedative medication has to be administered.

\subsubsection{Adolescents}

In adolescents, the main issue is undoubtedly the psychological acceptance of any invasive or troublesome process. It is therefore necessary to ensure that the interest of care, but also the technical considerations are well understood (for example, the kinetics of $\mathrm{HbS}$ recovery must be understood to accept the strict 4-week [or more depending on the postapheresis target and the habits of apheresis teams] interval between two sessions). The prevention of boredom includes video games, movies, multimedia, entertainments such as clowns or telling stories. Of note, the apheresis team becomes a referent team for adolescents with monthly or bi-monthly RBCX. This is of great importance at the time of transition into adult medicine units, since the RBCX are still performed in the same unit. 


\section{Adaptation of RBCX techniques to low weight in children}

\subsection{General principle: centrifugation}

The principle of RBCX consists of separating blood components by centrifugation, removing and replacing the patient's RBC by a donors non-SCD RBCs. The same apheresis devices are available for adults and children. To this extent, most of the several instruments available to perform RBCX, i.e. COBE Spectra or Optia Spectra (TerumoBCT) and COMTEC or Amicus (Fresenius Kabi), have been used for children (9,11-12, 22-25).

\subsection{Pediatric specificities}

Apheresis sessions in children must be adapted to the specific pediatric physiology. The most noticeable difference between adults and children concerns the TBV. Apheresis instruments require a defined patient's blood volume to fill the circuit, this volume being designated as the extracorporeal volume (ECV). When the ECV represents a large fraction of the TBV the children are exposed to a strong risk of hemodynamic complications and anemia, which was strongly addressed in the American consensus conference (16). In children with $\mathrm{SCD}$, the TBV does not resume the risk of acute hypovolemia as this risk also depends on Hct. Given that the normal Hct strongly depends on age, the basal Hct of children with SCD frequently stays below $20 \%$. As a result, for the same ECV, children with SCD do not tolerate acute RBC depletion as well as children with other non-hemolytic diseases. To that extent, ECVs of each instrument are $270 \mathrm{ml}, 185 \mathrm{ml}, 178 \mathrm{ml}$ and $160 \mathrm{~mL}$ for COBE Spectra, Spectra Optia, COM-TEC and Amicus, respectively. In practice, few adverse events were reported in studies of RBCX sessions using the COBE Spectra in children weighing more than $30 \mathrm{~kg}$ $(8,23)$ and RBCX sessions using Spectra Optia in children weighing more than $20 \mathrm{~kg}(22)$. However, the number of studies is too small to draw firm conclusions. Hence, for each child, 
in addition to ECV and TBV, pre-apheresis hemoglobin $(\mathrm{Hb})$ or Hct blood levels and comorbidities influence the decision to perform the RBCX with or without manipulations.

\subsection{Priming of the device: indications and techniques}

In the smallest children, when the ECVs are supposed to represent a large fraction of TBV, only one study discussed an RBC prime before RBCX when the patient's body weight is below $20 \mathrm{~kg}(22)$. However, this subject is debated among the apheresis teams and the American conference consensus recommended performing a priming with $\mathrm{RBC}$ when: i) the ECV is superior to $15 \%$ of TBV in children, ii) children weighing inferior to $20 \mathrm{~kg}$, or iii) complications as severe anemia, hemodynamic instability or cardiopulmonary disease (16). Some apheresis systems such as the Optia Spectra and Amicus include the recommendation to perform an RBC priming. When decided, the features of the prime are registered in the software including the volume of prime (corresponding to the ECV), the speed of priming flow and the Hct of the RBC used for priming. Then, the RBC selected for priming can be used with its native Hct or reconstituted with ABO-compatible plasma to obtain an Hct close to the pre-apheresis Hct of the patient's blood. To our mind, this latter possibility should be considered in children to prevent a transient hemoconcentration and hyperviscosity at the beginning of the procedures when the priming volume is reinfused, whereas only a low blood volume is removed from the patient. To our knowledge, no studies have characterized the RBCX procedures performed using a RBC prime in small children. From our point of view, studies and reports are required to describe and show the conditions to safely perform or refute RBCX in young children when considering both weight and pre-apheresis Hct. 


\subsection{Initial RBC depletion: infeasible and contraindicated in small children}

The other major difference between RBCX in adults and in children concerns the possibility performing isovolemic hemodilution-RBCX (IHD-RBCX). This technique consists of performing an initial RBC depletion whilst compensating with the same volume of colloids, albumin or saline to a minimal Hct blood level in the patient, and then in exchanging the SCD-RBCs whilst increasing the Hct to the post-apheresis target (26-27). In adults the advantages of IHD-RBCX are well-established and this technique allows the apheresis teams to save RBCUs or to space out the procedures (27). Guidelines from the American consensus conference recommend that IHD-RBCX are contraindicated in children with a body weight lower than $20 \mathrm{~kg}$ and in children with a low Hct, recent stroke, cardiopulmonary disease or hemodynamic instability (16). In our experience, we perform IHD only in children with a body weight higher than $40-45 \mathrm{~kg}$ as their Hct is often low. However, the volume of RBC saved depends on the pre-apheresis features of the patient (weight, height, TBV and Hct) and the low TBVs observed in young children do not allow us to save significant numbers of RBCUs or to significantly space out the procedures. There are only anecdotal data of IHDRBCX in children $(24,26)$.

\subsection{Rinseback: not appropriate in children}

In all patients the rinseback is discussed during $\mathrm{RBCX}$ procedures with the $\mathrm{COBE}$ Spectra technique as the device's software does not take into account this infused volume when calculating the post-apheresis parameters (Hct and the fraction of cells remaining, named FCR) (28). Guidelines from the American consensus conference did not recommend the rinseback in children when using both TerumoBTC devices as well as the IHD-RBCX as the rinseback volume could disturb the post-apheresis parameters (16). 


\section{Venous access in children with SCD}

Adequate vascular access represents a key issue to achieve successful RBCX sessions in children. Two main issues must have been resolved to perform apheresis procedures in children, i.e. maintaining a blood flow in the circuit and preventing the risk of clotting in the circuit. The blood flow that comes from the patient into the device has to be steady, which requires an appropriate vascular access site (29). Moreover, the risk of clotting into the disposable is increased in SCD-patients due to a chronic activation of coagulation inducing a hypercoagulable state and additionally in SCD-children with low inlet blood flow, making it essential to have a sustained flow in the circuit and an appropriate venous access (29-30).

Several factors have to be considered when prescribing a vascular access, such as: level of emergency, anteriority and anticipated needs for a central venous access, comorbidities (especially a prothrombotic state), and ease of peripheral access. In all cases, peripheral access has to be considered first. To that extent, Putensen et al. (31) reported that the large majority of procedures can be successfully performed as such, even in children (aged from 8 years). One way to improve the success of peripheral attempts is to use ultrasonography-guided vein identification, which has been successfully performed in RBCX by the same team (32). This approach has been successfully developed in adults but has to be evaluated in children, considering the age and the venous network in children with SCD (3132). Moreover, if possible, it should be advisable that the same trained person perform the cannulations throughout the apheresis program.

\subsection{What types of venous accesses can be used?}

\subsubsection{In acute $R B C X$ procedures}


In vital emergency indications (ACS, cerebral ischemia) a temporary double-lumen central venous catheter $(\mathrm{CVC})$ is often required to manage the overall care process. It should therefore be used for RBCX. However, even in the setting of a life-threatening event such as acute thoracic syndrome, guidelines as well as some teams consider that, when possible, peripheral venous accesses are ideal for RBCX because they can be placed only for the duration of the procedure $(16,29)$. Using CVC induces risks of complications such as pneumothorax, infections or thrombosis. To decrease or prevent these risks, these short-term $\mathrm{CVC}$ are put under sterile conditions in femoral veins and removed as early as possible. During vaso-occlusive crisis, peripheral access can be first considered. However, during crisis the inflammation and hypercoagulability states require one to frequently assure the function of the catheter with recurrent saline flushes of 10 to $20 \mathrm{~mL}$ or by locking the catheter using an anticoagulant solution.

\subsubsection{In regular program of $R B C X$}

4.1.2.1. Peripheral blood venous access

When considering the scheme of prophylactic apheresis treatments a broad consensus among the apheresis teams is that peripheral venous access should be the preferential venous access in adults and adolescents when possible. A recent study confirmed this preference with $80 \%$ of 1954 RBCX procedures successfully performed in 194 adults, adolescents and children during 2 years (31). However, in this study the younger children were 8-years old, as the peripheral antecubital venous network is not developed well enough in SCD-children under this age. American guidelines considered that in children as in adults a 16-18 gauge needle in an antecubital vein is required for blood withdrawal (16), whereas other authors considered that a 19-gauge to 20-gauge catheter is sufficient for the return (29). In children, the minimal flow rate is usually about $1 \mathrm{~mL} / \mathrm{kg} / \mathrm{minute}$. Hence, in a $20 \mathrm{~kg}$ child a 20 gauge 
catheter is used. Unfortunately, young SCD-children frequently display unsuitable peripheral venous accesses and other venous accesses are required.

\subsubsection{Short-term Central Venous Catheters (CVC)}

Flexible CVC include temporary and permanent catheters. External permanent catheters expose patients to the risks of infection and thrombosis, which reinforces the use of short-term (i.e. insertion several hours before RBCX and removal several minutes after its end) CVC to perform RBCX, which was evaluated in children during a 6-years follow-up (33). This solution has been considered appropriate to perform RBCX by various guidelines as American consensus conference and consensus report by the therapeutic subsection of the AABB $(16,34)$ (Table 2). Guidelines have indicated that the choice of the placement site depends on the expected duration with the femoral vein being preferred for short-term use, whereas the internal jugular (IJ) vein or subclavian vein was preferred for a medium-term use, IJ site being considered to predispose to less risk of infection and thrombosis $(16,35)$. For example, in case of severe infection requiring RBCX and IV antibiotics, such an access seems appropriate. A short-term CVC represents an appropriate solution to perform $\mathrm{RBCX}$, as we experienced almost $500 \mathrm{RBCX}$ procedures using insertion of short-term femoral CVCs in regular RBCX programs, showing appropriate tolerance, compliance, absence of infection or thrombosis (33). However, the risk of such an approach is to induce a venous sclerosis at sites of venous puncture. Then the venous structure at the insertion site after recurrent CVC placements throughout RBCX regular programs and years requires evaluations and therefore solutions when vessels become sclerotic. Furthermore, a systematic evaluation of the antecubital peripheral network should be done by trained and experienced nurses specialized in apheresis to limit the use of short-term CVC. 


\subsubsection{Long-term tunneled CVC}

Tunneled catheters and implanted ports can be used to perform RBCX (29). These disposables are prone to infections and thrombus formations in SCD patients due to a chronic activation of coagulation inducing a hypercoagulable state (30). Tunneled, double lumen Broviac catheters have been evaluated in peripheral stem cell harvesting in children but not in RBCX (36). Guidelines reported that tunneled catheters are prone to infections, whereas the disadvantages of ports and of some tunneled catheters include high a risk of thrombosis and low flow rate (16). To that latter extent, a recent study compared the flow rates of two ports used for RBCX in adults and adolescents, confirming the low flow rates in both ports (37). In some cases, the use of heparin rather than Acid-citrate Dextrose-A (ACD-A) (as the anticoagulant used to full the catheter at the end of procedures) can be more effective to prevent catheter obstruction. However, the best anticoagulant to use to prevent catheter obstruction must be studied considering the type of catheters, the age of the children (and their venous network development), the frequency of usage and the risk of a hypercoagulable state.

\subsubsection{Arterio-venous fistula (AVF)}

Arterio-venous fistula (AVF) represents a good vascular access to perform apheresis sessions. However, the hypercoagulable state in patients with SCD suggests a high risk of AVF thrombosis. The first use of AVF in a child (13 years- old) was published in 2002 (38). RBCX procedures were performed monthly without complications but the follow-up was short (18 months). The largest series reports the use of AVF during a subsequent follow-up (more than 4 years) in 26 SCD-patients. In this study, the younger children with an AVF were 13 years-old (39). Most patients with SCD were treated by RBCX within a small interval (4 to 
6 weeks). Only transient and curable complications occurred as thrombosis and infections. To our knowledge, this French team used AVF in young children aged 6 without complications (unpublished data). Therefore, we believe that AVF could be considered as a potent blood access in SCD but this approach requires more studies and necessitates identification of risks and so refutes this solution in patients with a high-risk for thrombosis.

\subsection{Prevention of clotting using anticoagulation}

Whichever the venous access used, the anticoagulant rate defined during RBCX sessions must be adapted in children to prevent clotting into the circuit. Moreover, the inlet blood flow must be sustained to prevent clotting in the initial inlet part of the catheter that is not anticoagulated. Therefore, this non-anticoagulated part of the circuit should be as limited as possible and the operator should have the ability to increase or decrease the inlet blood flow within acceptable values to prevent clotting. This technical particularity must be considered when developing apheresis devices.

The most frequently used anticoagulant is ACD-A. It acts by blocking the action of calcium in the clotting process. However, in some circumstances, heparin could be substituted or added to ACD-A.

The ratio of ACD-A used can be decreased considering the flow blood inlet, the preapheresis platelet blood levels and inflammation i.e. the hypercoagulable state. The use of increased amounts of ACD-A necessitates reinfusion of subsequent amounts of calcium gluconate to the outlet blood flow and a dosage of calcium gluconate perfusion depending on the age, body weight of the children and on the venous blood access used. 


\subsection{Venous access: conclusions}

Further studies are required to assess the best venous accesses for the children treated by RBCX depending on their age, the intervals between procedures and the indications of RBCX and the assumed duration of the regular RBCX program. In addition, in order to share their experience, apheresis teams should describe their own methods to prevent clotting in the circuit in small children treated by RBCX. Overall, we state that the best venous access depends on the team experience and logistical issues.

\section{Conclusion}

In conclusion, $\mathrm{RBCX}$ in children is a useful and effective therapy to treat and prevent severe SCD complications. However, several limitations require evaluation of the risk and complications to perform RBCX or to prefer manual RBC exchange. The smallest kids shall be referred to experienced centers, i.e. centers that perform a sufficient number of RBCX in pediatric patients. When RBCX is decided, adaptations of procedures are necessary in low weight children, as they are prone to hypovolemia and difficulties in blood venous access. Considering these limitations, the apheresis teams have to design specific monitoring during the sessions. In addition, apheresis teams can participate in the global management of the SCD patients, as they also can remain a referral team when the adolescent moves from management by a pediatric ward to an adult unit.

\section{REFERENCES}

1. Rees DC, Williams TN, Gladwin MT. Sickle-cell disease. Lancet 2010;376:2018-31.

2. Connes P, Renoux C, Romana M, Abkarian M, Joly P, Martin C, et al. Blood rheological abnormalities in sickle cell anemia. Clin Hemorheol Microcirc 2018; 68:165-72.

3. Connes P, Lamarre Y, Waltz X, Ballas SK, Lemonne R, Etienne-Julan M, et al. Haemolysis and abnormal haemorheology in sickle cell anaemia. Br J Haematol 2014;165:564-72.

4. Conran N, Belcher JD. Inflammation in sickle cell disease. Clin Hemorheol Microcirc 2018;68:263-99. 
5. Ballas SK. Sickle cell disease: Classification of clinical complications and approaches to preventive and therapeutic management. Clin Hemorheol Microcirc 2018;68:105-28

6. Taddesse A, Woldie IL, Khana P, Swerdlow PS, Chu JW, Abrams J, et al. Hypogonadism in patients with sickle cell disease: central or peripheral? Acta haematol 2012;128:65-8

7. Cela E, Vélez AG, Aquado A, Medin G, Bellon JM, Beléndez C. Chronic brain damage in sickle cell disease and its relation with quality of life. Med Clin (Barc) 2016;147:531-6

8. Dedeken L, Lê PH, Rozen L, El Kenz H, Huybrechts S, Devalck C, et al. Automated RBC exchange compared to manual exchange transfusion for children with sickle cell disease is cost-effective and reduces iron overload. Transfusion 2018;58:1356-62

9. Duclos C, Merlin E, Paillard C, Thuret I, Demeocq F, Michel G, et al. Long-term red blood cell exchange in children with sickle cell disease: manual or automatic? Transf Aph sci 2013;48:219-22

10. Kuo KH, Ward R, Kaya B, Howard J, Telfer P. A comparison of chronic manual and automated red blood cell exchange transfusion in sickle cell disease patients. Br J Haematol 2015;170:425-8

11. Saylors RL, Watkins B, Saccente S, Tang X. Comparison of automated red cell exchange transfusion and simple transfusion for the treatment of children with sickle cell disease acute chest syndrome. Pediatr Blood Cancer 2013;60:1952-6

12. Velasquez MP, Mariscalco MM, Goldstein SL, Airewele GE. Erythrocytapheresis in children with sickle cell disease and acute chest syndrome. Pediatr Blood Cancer 2009;53:1060-3

13. Schwartz J, Padmanabhan A, Aqui N, Balogun RA, Connelly-Smith L, Delaney M, et al. Guidelines on the Use of Therapeutic Apheresis in Clinical Practice-Evidence-Based Approach from the Writing Committee of the American Society for Apheresis: The Seventh Special Issue. J Clin Apheresis 2016;31:149-62

14. Adams RJ, McKie VC, Hsu L, Files B, Vishinski E, Pegelow C, et al. Prevention of a first stroke by transfusions in children with sickle cell anemia and abnormal results on transcranial Doppler ultrasonography. New Engl J Med 1998;339:5-11

15. Adams RJ, Brambilla D. Optimizing primary stroke prevention in sickle cell anemia (STOP 2) trial Investigators. Discontinuing prophylactic transfusions used to prevent stroke in sickle cell disease. N Engl J Med 2005;353:2769-78

16. Sarode R, Ballas SK, Garcia A, Kim HC, King K, Sachais B, et al. Red blood cell exchange: 2015 American Society for Apheresis consensus conference on the management of patients with sickle cell disease. J Clin Apher 2016;32:342-67

17. Woods D, Hayashi RJ, Binkley MM, Sparks GW, Hulbert ML. Increased complications of chronic erythracytopheresis compared to manual exchange transfusions in children and adolescents with sickle cell disease. Ped Blood Cancer 2017;64:e26635

18. Koehl B, Sommet J, Holvoet L, Abdoul H, Boizeau P, Ithier G, et al. Comparison of automated erythrocytapheresis versus manual to treat cerebral macrovasculopathy in sickle cell anemia. Transfusion 2016;56:1121-8

19. Grèze V, Chambon F, Merlin E, Rochette E, Isfan F, Déméocq F, et al. Leukapheresis in management of hyperleukocytosis in children's leukemia. J Pediatr Hematol Oncol 2014;36:e513-7

20. Sauret A, Rabiau N, Rochette E, Grèze V, Halle P, Ouachée M, et al. Shortened apheresis-based extracorporeal photochemotherapy for acute GVHD in children: a prospective study. Bone Marrow Transplant 2016;51:866-8

21. Cherqaoui B, Rouel N, Auvrignon A, Defachelles AS, Déméocq F, Kanold J, et al. Peripheral blood stem cell collection in low-weight children: a retrospective comparison of two apheresis devices. Transfusion 2014;54:1371-8

22. Perseghin P, Incontri A, Capra M, Pichler H, Witt V. Erythrocyte-exchange with the Optia ${ }^{\mathrm{TM}}$ cell separators in patients with sickle-cell disease. Transf Aph Sci 2013;28:411-5

23. Girard J, Tremisi PJ, Kassir A, Moullin T, Rigal D, Souillet G. Apheresis tolerance and acceptability in the child weighing $30 \mathrm{~kg}$ or less, with the exception of infants. Transfus Clin Biol 1996;3:297-304

24. Sipurzynski-Budrass S, Sovinz P, Lanzer G, Schallmoser K. Therapeutic red blood cell exchange in a child with sickle cell anaemia using the Spectra Optia ${ }^{\mathrm{R}}$ apheresis system. Transfus Med 2014,24:184-6

25. Govoni M. Erythroexchange in sickle cell disease. A three-step procedure to remove more haemoglobin S.

Blood Transfus 2015;13:340-1

26. Matesoyan K, Anderson C, Sarode R. Isovolemic hemodilution-red cell exchange for prevention of cerebrovascular accident in sickle cell anemia: the standard operating procedure. J Clin Aph 2012;27:88-92 27. Sarode R, Matevosyan K, Rogers ZR, Burner JD, Rutherford C. Advantages of isovolemic hemodilution-red cell exchange therapy to prevent recurrent stroke in sickle cell anemia patients. J Clin Aph 2011;26:200-7

28. Bhagat R, Matevosyan K, Jones R, Vetus ML, Burner J, Sarode R. Rinseback during red blood cell exchange with COBE Spectra does not affect fraction of cells remaining or post-exchange hematocrit. J Clin APh 2010;25:347-9 
29. Otrock KZ, Thibodeaux SR, Jackups Jr R. Vascular access for red blood cell exchange. Transfusion 2018;58(Suppl 1):569-79

30. Faes C, Sparkenbaugh EM, Pawlinski R. Hypercoagulable state in sickle cell disease. Clin Hemorheol Microcirc 2018;68:301-18

31. Putensen D, Leverett D, Patel B, Rivera J. Is peripheral access for apheresis procedures underuntilized in clinical practice?-A single centre experience. J Clin Aph 2016;32:501-6

32. Putensen D, Pilcher L, Collier D, McInermey K. Ultrasound-guided peripheral deep vein cannulation to perform automated red cell exchange-A pilot study in a single centre. J Clin Aph 2016;31:501-6

33. Billard M, Combet S, Hequet O, Kébaili K, Lorthois S, Pondarre C. Short-term femoral catheter insertion: a promising alternative to consistently allow long-term erythrocytapheresis therapy in children with sickle cell anemia. J Pediatr 2013;162:423-6

34. Biller E, Zhao Y, Berg M, Boggio L, Capocelli KE, Fang DC, et al. Red blood cell exchange in patients with sickle cell disease-indications and management: a review and consensus report by the therapeutic apheresis subsection of the AABB. Transfusion 2018;58:1965-72

35. Shönermarck U, Bosch T. Vascular access for apheresis in intensive care patients. Ther Apher Dial 2003;7:215-20

36. Leibundgut K, Müller C, Müller K, Ridolfi-Lüthy A, Hirt A. Tunneled, double lumen Broviac catheters are useful, efficient and safe in children undergoing peripheral blood progenitor cell harvesting and transplantation. Bone Marrow Transplant 1996;17:663-7

37. Lawicki S, Craig-Owens L, Bream Jr PR, Eichaum Q. Indwelling ports for prophylactic RBC exchanges in sickle cell patients: Comparison of bard and vortex ports. J Clin Aph 2018;33:666-70

38. Hartwig D 2002, Schläger F, Bucsky P, Kirchner H, Schlenke P. Successful long-term erythrocytapheresis therapy in a patient with symptomatic sickle-cell disease using an arterio-venous fistula. Transfus Med 2002;12:75-7

39. Delville M, Manceau S, Ait Abdallah N, Stolba J, Awad S, Damy T, et al. Arterio-venous fistula for automated red blood cells exchange in patients with sickle cell disease: Complications and outcome. Am J Hematol 2017;92:136-40 
Table 1. Recent studies about RBCX (or transfusions) performed in children with SCD

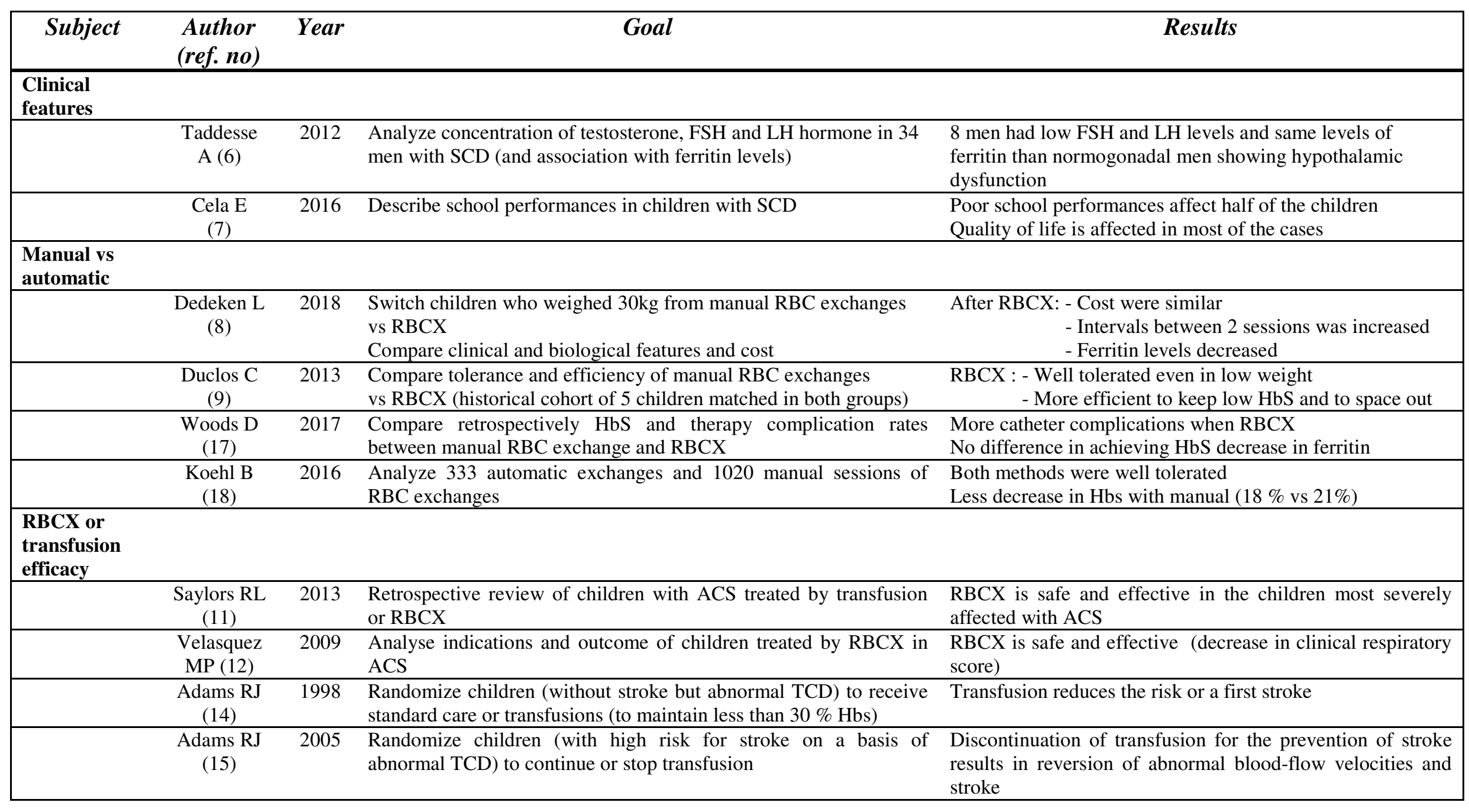

TCD : transcranial Doppler ultrasonography 
Table 1 (to be continued). Recent studies about RBCX (or transfusions) performed in children with SCD

\begin{tabular}{|c|c|c|c|c|}
\hline Subject & $\begin{array}{l}\text { Author } \\
\text { (ref. no) }\end{array}$ & Year & Goal & Results \\
\hline \multicolumn{5}{|l|}{$\begin{array}{l}\text { RBCX in } \\
\text { children }\end{array}$} \\
\hline & $\begin{array}{l}\text { Perseghin P } \\
(22)\end{array}$ & 2013 & Describe the tolerance and efficacy of Optia to perform RBCX & $\begin{array}{l}\text { All procedures were well tolerated } \\
\text { The smaller was a } 13 \mathrm{~kg} \text {-child }\end{array}$ \\
\hline & $\begin{array}{c}\text { Girard J } \\
(23) \\
\end{array}$ & 1996 & Describe various methods of apheresis in children & $\begin{array}{l}\text { Technical adaptations depending on TBV, Hct and type of } \\
\text { device or apheresis method allow an appropriate tolerance }\end{array}$ \\
\hline & $\begin{array}{l}\text { Sipurzynski- } \\
\text { Budrass S } \\
\text { (24) }\end{array}$ & 2014 & $\begin{array}{l}\text { Report of } 12 \text { RBCX sessions using a depletion step in a 11-year (40 } \\
\mathrm{kg} \text { ) child (using Optia method) }\end{array}$ & $\begin{array}{l}\text { Feasibility of RBCX using the depletion step in children } \\
\text { with appropriate weight }\end{array}$ \\
\hline & $\begin{array}{c}\text { Govoni M } \\
(25)\end{array}$ & 2015 & $\begin{array}{l}\text { Report of } 350 \text { RBCX sessions using a depletion step in } 10 \text { patients } \\
\text { ( } 4 \text { children) (using COM-TEC method) }\end{array}$ & $\begin{array}{l}\text { Feasibility of RBCX using the depletion step in children } \\
\text { using COM-TEC }\end{array}$ \\
\hline \multicolumn{5}{|c|}{ 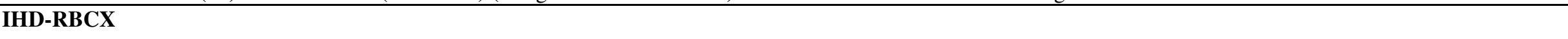 } \\
\hline & $\begin{array}{l}\text { Matevosyan } \\
\mathrm{K}(26)\end{array}$ & 2012 & Describe the procedure developed to perform the IHD-RBCS & $\begin{array}{l}\text { Two-phase procedure that combines RBC depletion and } \\
\text { RBCX }\end{array}$ \\
\hline & $\begin{array}{c}\text { Sarode } \\
(27)\end{array}$ & 2011 & Describe the advantages of IHD-RBCX & IHD-RBCX required $11 \%$ fewer $\mathrm{RBC}$ units \\
\hline \multicolumn{5}{|l|}{$\begin{array}{l}\text { Venous } \\
\text { access }\end{array}$} \\
\hline & $\begin{array}{l}\text { Putensen D } \\
\text { (31) }\end{array}$ & 2016 & $\begin{array}{l}\text { Analyse the venous access used during numerous apheresis } \\
\text { sessions }\end{array}$ & $\begin{array}{l}80 \% \text { of } 1954 \text { RBCX (total of } 194 \text { patients) were performed } \\
\text { using peripheral venous access and } 10 \% \text { of the sessions were } \\
\text { performed using CVC }\end{array}$ \\
\hline & $\begin{array}{c}\text { Billard M } \\
(33)\end{array}$ & 2013 & $\begin{array}{l}\text { Analyse and follow children with short-term CVC for regular } \\
\text { RBCX program }\end{array}$ & $\begin{array}{l}\text { Short-term CVC are appropriate to perform RBCX and are } \\
\text { well tolerated during a 6-year follow-up }\end{array}$ \\
\hline & $\begin{array}{c}\text { Delville M } \\
(39)\end{array}$ & 2017 & $\begin{array}{l}\text { Analyse the complications of AVF in adolescents and adults treated } \\
\text { by RBCX }\end{array}$ & $\begin{array}{l}\text { AVF infections, stenosis and thrombosis were frequent but } \\
\text { easily treated }\end{array}$ \\
\hline
\end{tabular}

IHD-RBCX = isovolemic hemodilution-RBCX

$\mathrm{AVF}=$ arterio-venous fistula 
Table 2. Recent recommendations and guidelines for RBCX

\begin{tabular}{|c|c|c|c|c|}
\hline $\begin{array}{l}\text { Origin of } \\
\text { Guidelines }\end{array}$ & $\begin{array}{l}\text { Author } \\
\text { (ref. no) }\end{array}$ & Year & Goal & Results \\
\hline ASFA & $\begin{array}{c}\text { Schwartz J } \\
\text { (13) }\end{array}$ & 2016 & $\begin{array}{l}\text { Guidelines for the use of therapeutic apheresis in clinical practice } \\
\text { Committee of the American Society for apheresis }\end{array}$ & $\begin{aligned} \text { Give recommendations for } \mathrm{RBCX} \text { in : } \\
-\quad \text { Acute } \mathrm{SCD} \text { complications } \\
-\quad \text { Non acute complications for SCD }\end{aligned}$ \\
\hline $\begin{array}{l}\text { ASFA } \\
\text { consensus } \\
\text { conference }\end{array}$ & $\begin{array}{c}\text { Sarode R } \\
\text { (16) }\end{array}$ & 2017 & $\begin{array}{l}\text { Guidelines for RBCX } \\
2015 \text { American Society for Apheresis consensus conference on } \\
\text { the management of patients with SCD }\end{array}$ & $\begin{array}{l}\text { Guidelines and recommendations for: } \\
\text { - Physiopathology of SCD } \\
\text { - Management of stroke } \\
\text { - Rationale for RBCX in ACS } \\
\text { - RBCX and IHD } \\
\text { - Optimal targets for Hct and HbS } \\
\text { - Challenges for performing RBCX in small } \\
\text { children } \\
\text { - Venous access for RBCX } \\
\text { - Selection for RBC units }\end{array}$ \\
\hline $\begin{array}{l}\text { Subsection of } \\
\text { AABB }\end{array}$ & $\begin{array}{c}\text { Biller E } \\
(34)\end{array}$ & 2018 & $\begin{array}{l}\text { Consensus report by the therapeutic apheresis subsection } \\
\text { of the subsection of AABB }\end{array}$ & $\begin{aligned} & \text { Guidelines and recommendations for : } \\
& \text { - } \text { Simple transfusion vs RBCX } \\
&- \text { Indications for RBCX } \\
&- \text { Vascular access } \\
&- \text { RBC units } \\
&- \text { Target Hb and/or Hct } \\
&- \text { Target HbS level } \\
&- \text { RBC IHD Depletion }\end{aligned}$ \\
\hline
\end{tabular}

ACS $=$ acute chest syndrome

$\mathrm{IHD}=$ isovolemic hemodilution 